\title{
Review of thyroid profile in patients with heavy menstrual bleeding in a tertiary care hospital
}

\author{
Pooja R.*, Tushar Palve, Sneha Mutyapwar, Payal Saha
}

Department of Obstetrics and gynaecology, GGMC, Mumbai, Maharashtra, India

Received: 21 October 2021

Revised: 21 November 2021

Accepted: 22 November 2021

\section{*Correspondence:}

Dr. Pooja R.,

E-mail: poojaleena1995@gmail.com

Copyright: ( ) the author(s), publisher and licensee Medip Academy. This is an open-access article distributed under the terms of the Creative Commons Attribution Non-Commercial License, which permits unrestricted non-commercial use, distribution, and reproduction in any medium, provided the original work is properly cited.

\begin{abstract}
Background: Heavy menstrual bleeding (HMB) is defined as excessive menstrual blood loss which interferes with a woman's physical, social, emotional and/or material quality of life. It can occur alone or in combination with other symptoms. Thyroid hormone affects menstrual pattern. The objective of this study was to evaluate thyroid function in women with menorrhagia (HMB).

Methods: It is a type of journal article. Study design- retrospective study. The present study was conducted in the Department of obstetrics and Gynecology, cama and albess hospital, Mumbai, Maharashtra, India, from a period of January 2021 to July 2021, 51 women of reproductive age group between menarche-menopause with HMB. Quantitative determination of T3, T4 and TSH by CLIA estimated in autoanalyser.

Results: About 51 women participated in the study in which most of the subjects belong to 45-49 years of age group. Maximum patients are multipara. Commonest cause of menorrhagia is fibroid. Most females with menorrhagia are euthyroid. Most of patients with HMB are $\mathrm{O}+\mathrm{ve}$. In most of the patients, anaemia due to HMB is treated by blood transfusion.

Conclusions: Biochemical evaluation of thyroid function tests should be compulsory in all patients with menorrhagia to detect thyroid dysfunction. Most females with menorrhagia are euthyroid.
\end{abstract}

Keywords: Heavy menstrual bleeding, Menorrhagia, Thyroid function

\section{INTRODUCTION}

Heavy menstrual bleeding (HMB) is defined as excessive menstrual blood loss which interferes with a woman's physical, social, emotional and/or material quality of life. It can occur alone or in combination with other symptoms. It is a type of abnormal uterine bleeding (AUB). ${ }^{1,2}$

Abnormal uterine bleeding can be caused by structural abnormalities in the reproductive tract, anovulation, bleeding disorders, hormone issues (such as hypothyroidism) or cancer of the reproductive tract. Initial evaluation aims at figuring out pregnancy status, menopausal status, and the source of bleeding. One definition is bleeding lasting more than 7 days or the loss of more than $80 \mathrm{~mL}$ of blood heavy flow. ${ }^{3,4}$

Initial treatment often involve birth control pills. Tranexamic acid, danazol, progesterone IUDs, and NSAIDs are also helpful. ${ }^{5}$ Surgery can be an effective for those whose symptoms are not well-controlled with other treatments. ${ }^{6}$

HMB is one of the most common reasons for gynaecological consultations in both primary and secondary care. About 1 in 20 women aged between 30 and 49 years consult their GP each year because of heavy periods or menstrual problems, and menstrual disorders comprise $12 \%$ of all referrals to gynaecology services. 
The focus of this guideline is on women of reproductive age (after puberty and before the menopause) with $\mathrm{HMB}$, including women with suspected or confirmed fibroids, and women with suspected or confirmed adenomyosis. The guideline does not primarily cover women with gynaecological bleeding other than HMB (for example, intermenstrual bleeding or postcoital bleeding) or with gynaecological conditions in which HMB is not the main symptom (such as endometriosis). Outpatient management comprising insertion of a levonorgestrel-releasing intrauterine system (LNG-IUS) has increased in popularity in recent years, and there has been a reduction in surgical procedures.

Thyroid disorders have profound effect on female reproductive system in terms of delayed puberty, AUB, infertility, RPL, premature menopause. Thyroid disorders are 10 times more common in females than males. ${ }^{7-9}$

The underlying cause of AUB is uncertain but most common associated basic pathology is ovarian dysfunction and consequent hormonal imbalance. Ovarian dysfunction may be primary (pathological lesion of ovary) or secondary to endocrine dysfunction exampleHypothalamus, pituitary and thyroid.

Majority of cases of subclinical hypothyroidism patients are asymptomatic. ${ }^{10,11}$ Serum TSH assay is a sensitive indicator of hypothyroidism because TSH levels elevates before circulating thyroxin level fall below normal range. Thyroid gland is one of the most vital endocrine organs which plays a major role in growth, development, metabolism and function of every organ in the body. Both Hypo and Hyperthyroidism can result in menstrual irregularities.

The mechanism by which the thyroid disorders is associated with AUB may be explained by altering thyroid stimulating hormone (TSH) response, increasing prolactin levels, altering luteinizing hormone (LH) response, affecting peripheral conversion of androgens to estrogens, altering sex hormone binding globulin (SHBG) and affecting coagulation pathways in addition to effect on lipid profile. ${ }^{12}$

The objective of this study was to estimate the prevalence of thyroid dysfunctions in women with HMB from puberty to menopause; and to evaluate thyroid function test in women with HMB; and to assess the menstrual pattern in women with thyroid dysfunction.

\section{METHODS}

The present study is a type of research article was conducted in the department of obstetrics and gynaecology, Cama hospital, Mumbai from January 2021 to July 2021, 51 women of reproductive age, menarche to menopause with heavy menstrual bleeding were selected.

\section{Selection criteria}

Women of reproductive age group with heavy menstrual bleeding, non-pregnant.

\section{Study design}

The study design was retrospective.

\section{Procedure}

After taking detailed history regarding age, parity, marital status, menstrual complaints such as heavy menstrual bleeding, general Physical examination along with pelvic examination was carried out. Complete blood count, T3, T4 and TSH, FBS, PPBS, blood group.

Special investigations were done in necessary cases such as transvaginal scan, endometrial sampling and hysteroscopy.

\section{Statistical analysis}

Statistical analysis is done by Statistical package for social sciences (SPSS) software and Difference with a $\mathrm{p}$ value of $<0.05$ was considered statistically significant.

\section{RESULTS}

There were 51 women included in the study.

Table 1: Distribution of patients according to age intervals.

\begin{tabular}{|lll|}
\hline Age (years) & $\begin{array}{l}\text { No. of } \\
\text { patients }\end{array}$ & Percentage \\
\hline Menarche-19 & 4 & 7.8 \\
\hline $\mathbf{2 0 - 2 4}$ & 3 & 5.88 \\
\hline $\mathbf{2 5 - 2 9}$ & 2 & 3.92 \\
\hline $\mathbf{3 0 - 3 4}$ & 1 & 1.96 \\
\hline $\mathbf{3 5 - 3 9}$ & 6 & 11.76 \\
\hline $\mathbf{4 0 - 4 4}$ & 9 & 17.64 \\
\hline $\mathbf{4 5 - 4 9}$ & 20 & 39.2 \\
\hline $\mathbf{2 5 0}$ - menopause & 6 & 11.76 \\
\hline
\end{tabular}

Table 2: Distribution of patients according to marital status.

\begin{tabular}{|lll|}
\hline Marital status & $\begin{array}{l}\text { No. of } \\
\text { patients }\end{array}$ & Percentage \\
\hline Married & 44 & 86.24 \\
\hline Unmarried & 7 & 13.72 \\
\hline
\end{tabular}

Most of the subjects belong to 45-49 years followed by 4044 years showing 40-49 years age group are most effected group in this study (Table 1). Among 51 cases of HMB, most of the subjects are married $(86.27 \%)$ and $13.72 \%$ are unmarried (Table 2). Most of the patients are multipara -35 patients $(68.62 \%)$ followed by nullipara -9 patients $(17.64 \%)$ and primipara -7 patients $(13.72 \%)$ (table 3$)$. 
Most of the subjects of HMB are $\mathrm{O}+\mathrm{ve}(27.45 \%)$ followed by $\mathrm{B}+\mathrm{ve}$ (25.49) (Table 4).

Table 4: Distribution of patients according to parity.

\begin{tabular}{|lll|}
\hline Parity & $\begin{array}{l}\text { No. of } \\
\text { patients }\end{array}$ & Percentage \\
\hline Nullipara & 9 & 17.64 \\
\hline Primipara & 7 & 13.72 \\
\hline Multipara & 35 & 68.60 \\
\hline
\end{tabular}

Table 5: Distribution of patients according to blood group.

\begin{tabular}{|lll|}
\hline Blood group & $\begin{array}{l}\text { No. of } \\
\text { patients }\end{array}$ & Percentage \\
\hline A+ & 8 & 15.68 \\
\hline A- & 2 & 3.92 \\
\hline B+ & 13 & 25.48 \\
\hline O+ & 8 & 15.68 \\
\hline O- & 2 & 3.92 \\
\hline AB+ & 14 & 27.44 \\
\hline AB- & 1 & 1.96 \\
\hline
\end{tabular}

Table 5: Distribution of patients according to thyroid function.

\begin{tabular}{|lll|}
\hline Thyroid status & $\begin{array}{l}\text { No. of } \\
\text { patients }\end{array}$ & Percentage \\
\hline Euthyroid & 36 & 70.5 \\
\hline $\begin{array}{l}\text { Subclinical } \\
\text { hypothyroidism }\end{array}$ & 10 & 19.6 \\
\hline $\begin{array}{l}\text { Profound } \\
\text { Hypothyroidism }\end{array}$ & 3 & 5.88 \\
\hline Hyperthyroidism & 2 & 3.92 \\
\hline
\end{tabular}

Table 6: Distribution of patients according to causes of HMB (USG based).

\begin{tabular}{|lll|}
\hline Causes of hmb & $\begin{array}{l}\text { No. of } \\
\text { patients }\end{array}$ & Percentage \\
\hline Fibroid & 20 & 39.20 \\
\hline Adenomyosis & 7 & 13.72 \\
\hline Carcinoma & 1 & 1.96 \\
\hline $\begin{array}{l}\text { Thickened } \\
\text { Endometrium }\end{array}$ & 9 & 17.64 \\
\hline Polyp & 5 & 9.8 \\
\hline Ovarian cyst & 1 & 1.96 \\
\hline Normal usg & 8 & 15.68 \\
\hline
\end{tabular}

In the present study, $70.5 \%$ of women are euthyroid,5.88 $\%$ of women were profound hypothyroid, $19.6 \%$ had subclinical hypothyroidism and $3.92 \%$ of women had hyperthyroidism (Table 5).

Table 7: Modalities to treat anaemia due to HMB.

\begin{tabular}{|lll|}
\hline Modality & $\begin{array}{l}\text { No. of } \\
\text { patients }\end{array}$ & Percentage \\
\hline Blood transfusion & 22 & 78.57 \\
\hline Inj FCM & 4 & 14.28 \\
\hline Inj iron sucrose & 2 & 7.14 \\
\hline
\end{tabular}

Table 8: Different methods for treating HMB.

\begin{tabular}{|lll|}
\hline Methods & $\begin{array}{l}\text { No. of } \\
\text { patients }\end{array}$ & Percentage \\
\hline Mirena & 2 & 4.8 \\
\hline Polypectomy & 3 & 7.31 \\
\hline CT,RT & 2 & 4.8 \\
\hline OCP & 7 & 17.07 \\
\hline $\begin{array}{l}\text { Progesterone } \\
\text { Support }\end{array}$ & 4 & 9.75 \\
\hline $\begin{array}{l}\text { Inj Leuprolide(Gnrh } \\
\text { analogue) }\end{array}$ & 3 & 7.31 \\
\hline $\begin{array}{l}\text { Hysteroscopic D and } \\
\text { C }\end{array}$ & 3 & 7.31 \\
\hline D And C & 8 & 19.2 \\
\hline LAVH & 1 & 2.4 \\
\hline TAH & 8 & 19.2 \\
\hline
\end{tabular}

Most common cause of HMB in this study is fibroid (39.21\%) (Table 6). In this study, $27.45 \%$ are having diabetes mellitus, $13.72 \%$ have hypertension (Table 7 ). About $43.13 \%$ of subjects are transfused by blood, $8 \%$ by inj FCM, $4 \%$ by inj iron sucrose to treat anaemia due to HMB (Table 8).

\section{DISCUSSION}

Heavy menstrual bleeding is accompanied by low quality of life attributed to treatment efforts of bleeding and outcomes of high blood loss like fatigability and anemia. ${ }^{14}$ The endocrine disturbances play a major role in pathogenesis of heavy menstrual bleeding. ${ }^{14}$ It needs repeated curettage and hysterectomy associated with its mortality and morbidity. In many of the cases, the cause is usually not apparent. Sometimes heavy menstrual bleeding may be only presenting complain in hypothyroid women.

Gowri et al, showed prevalence of hypothyroidism in women in the reproductive age (20-40 years) varies between $2-4 \%$. In the general population, the prevalence of subclinical hyperthyroidism is around $1.5 \% .^{15}$

In the present study, $70.5 \%$ of women are euthyroid, 5.88 $\%$ of women were profound hypothyroid, $19.6 \%$ had subclinical hypothyroidism and $3.92 \%$ of women had hyperthyroidism.

Joshi et al, found $68 \%$ of menstrual abnormalities in 22 women with hypothyroidism compared to only $12 \%$ in 49 controls. $^{16}$ 
In the study by Krassas et al, the prevalence of menstrual irregularities (mainly oligomenorrhoea) reached $23 \%$ among 171 hypothyroid patients, while being only $8 \%$ in 214 controls $(\mathrm{p}<0.05) .{ }^{17}$

Timely detection of thyroid dysfunction in women presenting with AUB and its proper management can prevent unnecessary surgical interventions and helps to reduce financial burden and improves quality of life. Hence this study is undertaken to evaluate the thyroid dysfunction in women with heavy menstrual bleeding.

The mechanism by which the hypothyroidism can affect the menstrual cycle is not fully understood. However, some authors attributed this relationship to irregular or no ovulation that decreases the luteinizing hormone and elevating the estrogen leading to menstrual bleeding.

\section{Limitations}

Detailed menstrual history should be collected. Medical causes of heavy menstrual bleeding should be ruled out. All basic lab investigation to be done to come for diagnosis.

\section{CONCLUSION}

As there is high incidence of thyroid diseases in women with abnormal uterine bleeding are to be screened. This would also avoid unnecessary hormonal treatment and surgery in these patients. It concludes that thyroid disorder should be considered as an important aetiological factor for menstrual abnormality. Thus, biochemical evaluation T3, T4 and TSH estimations should be made mandatory in AUB cases to detect profound and subclinical thyroid dysfunction. We found most of the women with heavy menstrual bleeding were euthyroid. In our study among hypothyroid patients most common complaint of abnormal uterine bleeding was heavy menstrual bleeding.

Funding: No funding sources

Conflict of interest: None declared

Ethical approval: The study was approved by the Institutional Ethics Committee

\section{REFERENCES}

1. Munro MG, Critchley HO, Broder MS, Fraser IS.FIGO classification system (PALM-COEIN) for causes of abnormal uterine bleeding in nongravid women of reproductive age. International Journal of Gynaecology and Obstetrics. 2011;113(1):3-13.

2. Bacon JL. Abnormal Uterine Bleeding: Current Classification and Clinical Management. Obstetrics and Gynecology Clinics of North America. 2014;44(2):179-93.
3. O'Brien SH. Evaluation and management of heavy menstrual bleeding in adolescents: the role of the hematologist".Hematology. 2018;30(1):390-8.

4. Committee on Practice Bulletins: Gynecology. Practice bulletin no. 136: management of abnormal uterine bleeding associated with ovulatory dysfunction. Obstetrics and Gynecology. 2013;122(1):176-85.

5. Rodriguez BM, Lethaby A, Farquhar C. Non-steroidal anti-inflammatory drugs for heavy menstrual bleeding". The Cochrane Database of Systematic Reviews. 2019;9:CD000400.

6. Marjoribanks J, Lethaby A, Farquhar C. Surgery versus medical therapy for heavy menstrual bleeding". The Cochrane Database of Systematic Reviews. 2016;(1):CD003855.

7. Davey DA, Dewhurst. Text book of obstetrics and gynaecology for post graduates. 5th edn; 1990:590600.

8. Thomas R, Reid RL. Thyroid disease and reproductive dysfunctions. Obstet Gynaecol. 1987;70:789-98.

9. Berek JS, Adarshi EY, Hillard PA. In endocrine disorders. Novaks Gynaecology 12th edn. Williums and Wilkins, Gopson paper ltd Noida. 2001;864.

10. Olive D, Palter S. Reproductive Physiology. In: Berek JS, eds. Berek and Novaks Gynaecology. 14th ed Philadelphia: Lippincott Williams and Wilkins Company. 2002;161-86.

11. Thomas R. Reid RL. Thyroid diseases and reproductive dysfunction. Obstet Gynaecol. 1987;70:789-98.

12. Byna P, Siddula S, Kolli S, Shaik MV. Thyroid abnormality in perimenopausal women with abnormal uterine bleeding. Int J Res Med Sci. 2015;3(11):32503.

13. Liu Z, Doan QV, Blumenthal P, Dubois RW. A systematic review evaluating health related quality of life, work impairment and health care costs and its utilization in abnormal uterine bleeding. Value Health. 2007;10(3):183-94.

14. Deshmukh PY, Boricha BG, Pandey A. The association of thyroid disorders with abnormal uterine bleeding. 2015.

15. Gowri M, Radhika BH, Harshini V, Ramaiaha R. Role of thyroid function tests in women with abnormal uterine bleeding. Int $\mathbf{J}$ Reprod Contracept Obstet Gynecol. 2014;3:54-7.

16. Joshi JV, Bhandarkar SD, Chadha M, Balaiah D, Shah R. Menstrual irregularities and lactation failure may precede thyroid dysfuction or goitre. J Postgraduate Med. 1993;39:137-41.

17. Kaltsas J, Paunkovic N, Kaltsas T, Papadopoulou P, Paunkovic J. Disturbances of menstruation in hypothyroidism. Clin Endocrinol. 1999;50:655-9.

Cite this article as: Pooja R, Palve T, Mutyapwar S, Saha P. Review of thyroid profile in patients with heavy menstrual bleeding in a tertiary care hospital. Int J Reprod Contracept Obstet Gynecol 2021;10:4460-3. 